\title{
Rewaloryzacja zabytkowego Gmachu Technologii Chemicznej w Zespole Politechniki Warszawskiej
}

\author{
Anna Agata Wagner \\ Zakład Dziedzictwa Architektonicznego i Sztuki, Wydział Architektury, \\ PolitechnikaWarszawska,e-mail: agata.wagner@pw.edu.pl
}

Streszczenie: Gmach Technologii Chemicznej powstał w latach 30. XX wieku. Jest jednym z dwóch gmachów, autorstwa ówczesnego dziekana Wydziału Architektury prof. Czesława Przybylskiego, wchodzących w skład zabytkowego zespołu Politechniki Warszawskiej. Gmach zaprojektowano z uwzględnieniem specyficznych rozwiązań funkcjonalnych i technologicznych, w oparciu o najnowsze wówczas wzorce europejskie i amerykańskie. W architektonicznej formie Przybylski nawiązał do geometrycznych nurtów awangardowych. W wieloczłonowej, kaskadowo spiętrzonej bryle wydobył elementy strukturalne, potraktowane w sposób rzeźbiarski, przy jednoczesnym zachowaniu jedności funkcji i formy. Całość wpisała się w bryłowo-fakturowy warszawski funkcjonalizm nurtu „szarej cegły”.

Gmach uległ znacznym zniszczeniom w czasie Powstania Warszawskiego (zniszczenia stropów, wypalenie wnętrz). Powojenna odbudowa i modernizacje nastawione były na usprawnienie i intensyfikację funkcji utylitarnych, z pominięciem odtworzeń pierwotnych układów i historycznego wystroju.

Ostatnie dekady przyniosły zmianę podejścia do zabytkowych gmachów Politechniki. Jest to doskonale widoczne m.in. na przykładzie gmachu Technologii Chemicznej, gdzie od kilku lat trwają prace remontowo-modernizacyjne, mające na celu przywrócenie świetności elewacjom i adaptację wnętrz na nowoczesne laboratoria. Istotnym elementem tych działań jest rewaloryzacja holu wejściowego i głównej auli wykładowej. Przeprowadzone prace wykonano w oparciu o badania historyczno-konserwatorskie. Dzięki zachowanemu oryginalnemu projektowi prof. Czesława Przybylskiego możliwa była przestrzenna rekonstrukcja audytorium i przywrócenie pierwotnego układu wnętrzom holu wejściowego. Użycie nowoczesnych rozwiązań technologicznych i materiałowych nadało wnętrzom współczesny charakter, bez znamion stylizacji, przy jednoczesnym odtworzeniu cech charakterystycznych projektu prof. Przybylskiego. Dobra współpraca pomiędzy administratorami gmachu, architektem, historykiem architektury i służbami konserwatorskimi zaowocowała dobrym efektem końcowym - przywróceniem wartości architektonicznych przy jednoczesnym podniesieniu walorów funkcjonalnych zabytkowemu gmachowi Technologii Chemicznej, wybitemu przedstawicielowi przedwojennego warszawskiego modernizmu.

Słowa kluczowe: zabytkowy gmach Politechniki Warszawskiej, przedwojenny warszawski modernizm, Czesław Przybylski, rewaloryzacja, modernizacja, adaptacja.

\section{Wstęp}

Gmach Technologii Chemicznej jest wybitnym przedstawicielem warszawskiego międzywojennego modernizmu, wpisującego się w bryłowo-fakturowy nurt „,szarej cegły”. Jego powojenna odbudowa i modernizacje nastawione były na intensyfikację funkcji utylitarnych, 
z pominięciem odtworzeń pierwotnych układów i historycznego wystroju. Zmiana podejścia do zabytkowych gmachów Politechniki przełożyła się w ostatnich dekadach na świadome zabiegi rewaloryzacyjne, mające na celu przywrócenie im częściowo zatraconych wartości architektonicznych. Przykładem tych działań jest gmach Technologii Chemicznej Politechniki Warszawskiej.

\section{Historia Gmachu Technologii Chemicznej PW}

Gospodarczy rozwój młodego państwa i powstanie nowych gałęzi przemysłu, ukierunkowanego w dużym stopniu na zagadnienia obronności, wymagały utworzenia na Politechnice Warszawskiej odpowiednich, nowocześnie wyposażonych placówek badawczo-dydaktycznych. Kolejne gmachy wchodzące w skład zespołu uczelni powstałe w latach międzywojennych, były właśnie inwestycjami wynikającymi z konkretnych potrzeb rozbudowującego się przemysłu. Ponieważ na terenie posiadanym przez Politechnikę nie było miejsca na nowe obiekty, uczelnia uzyskała od władz miejskich działkę o powierzchni 26,6 tysięcy $\mathrm{m}^{2}$, która była częścią dawnej szkółki drzew owocowych, zlokalizowaną wzdłuż ulicy Topolowej (dzisiejsza Al. Niepodległości), pomiędzy ulicami Nowowiejską i Koszykową.

Gmach Technologii Chemicznej wraz z gmachem Elektrotechniki zostały zaprojektowane przez wybitnego architekta, profesora Czesława Przybylskiego (1880-1936) i wzniesione w latach 1930-1934.

W celu zrealizowania budowy gmachów zawiązano w 1928 roku specjalne stowarzyszenie - „Studium Technologiczne” z udziałem przedstawicieli rządu, nauki, przemysłu i wojska. Patronat nad całością przedsięwzięcia objął prezydent Ignacy Mościcki, profesor elektrochemii.

Projekty gmachów wymagały specyficznych rozwiązań funkcjonalnych i technologicznych, dlatego też potrzebne było oparcie się na najnowszych wzorach europejskich i amerykańskich. W przypadku gmachu Technologii Chemicznej wykorzystane zostały materiały przesłane przez polskich uczonych działających lub znających techniczne realia funkcjonowania laboratoriów badawczych w Niemczech, Danii, Holandii i USA.

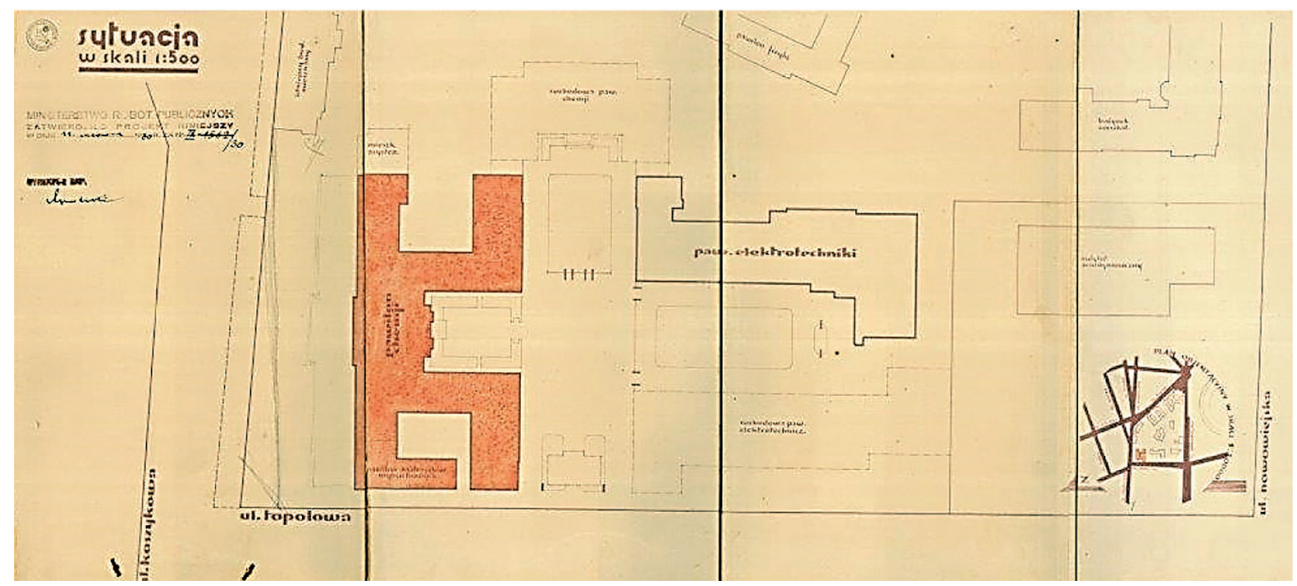

Rys. 1. Plan sytuacyjny gmachu Technologii Chemicznej, wg [1] 


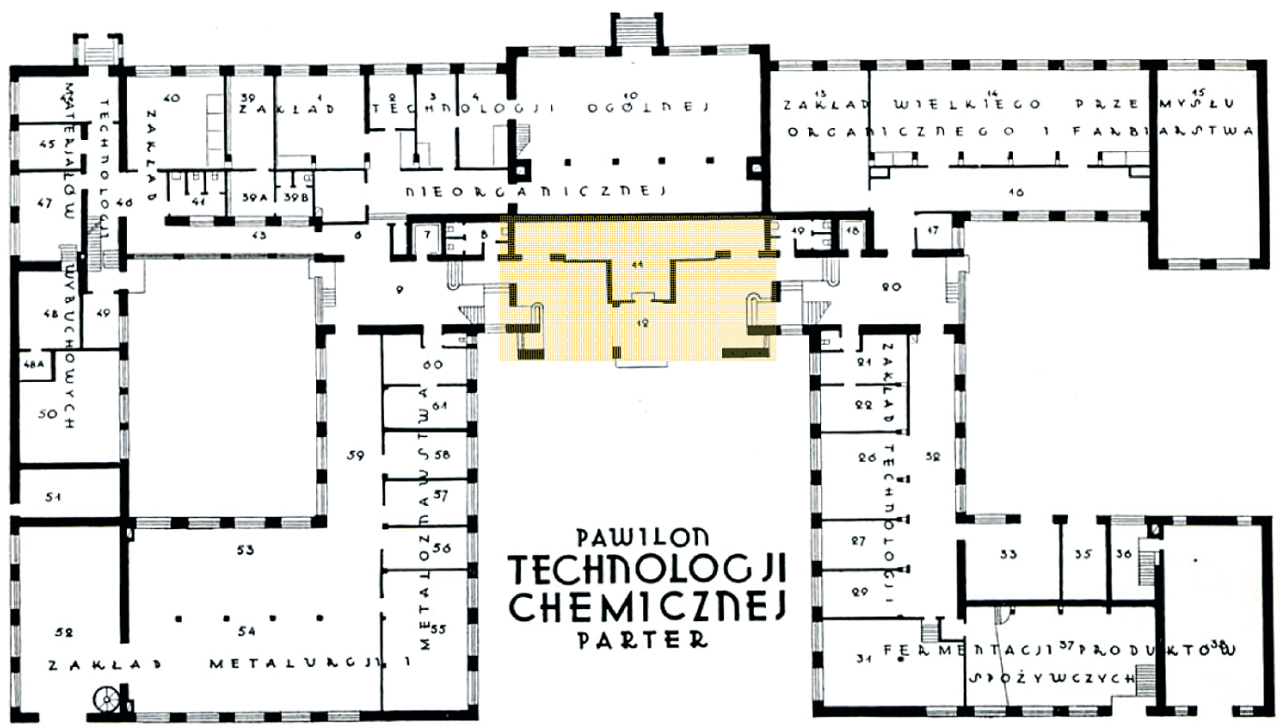

Rys. 2. Rzut parteru, wg [2]

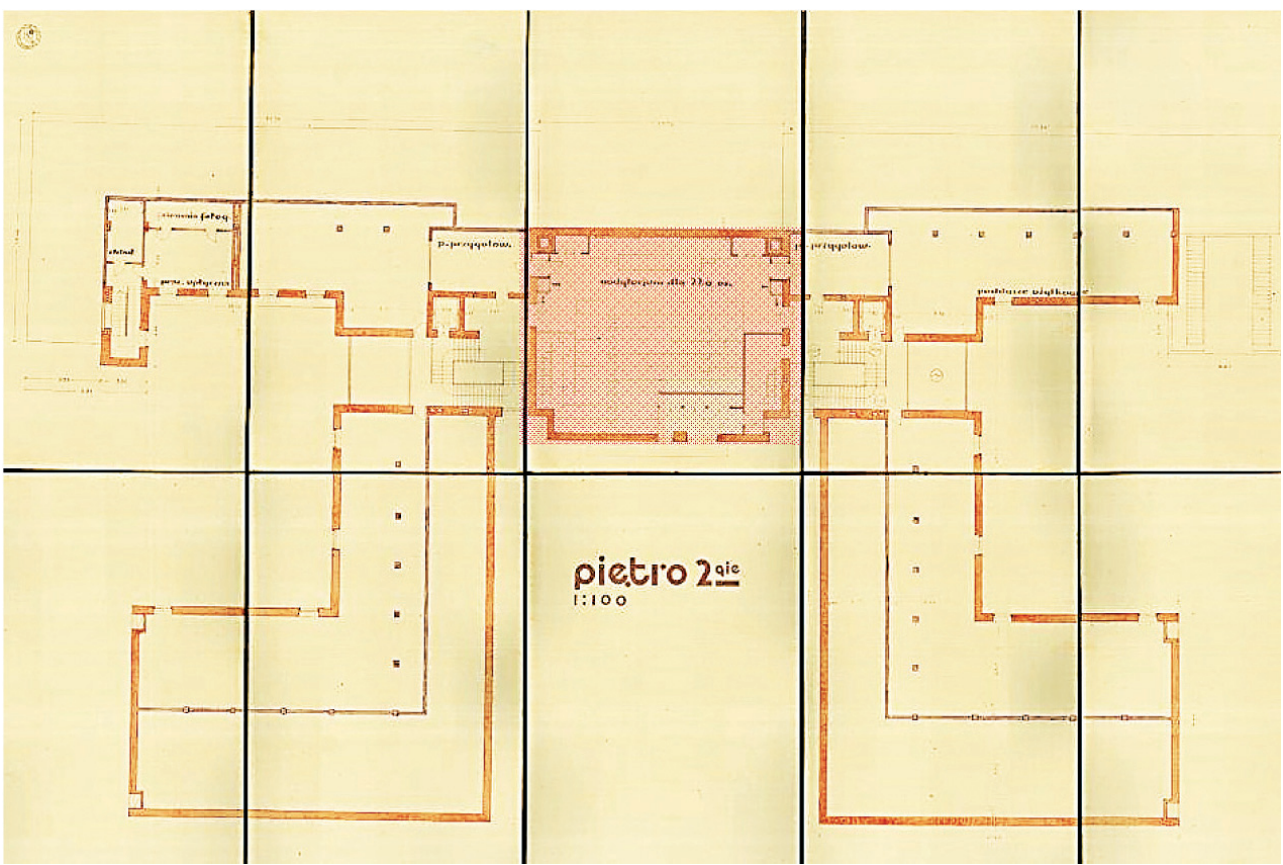

Rys. 3. Rzut najwyższej kondygnacji z widocznym planem wnętrza dużego audytorium, wg [1]

Wieloskrzydłowy gmach stanął w narożniku pomiędzy ul. Koszykową a Al. Niepodległości, ale został znacznie odsunięty od ul. Koszykowej. Główne wejście architekt umieścił od strony południowej, wnętrza dziedzińca politechnicznego. Podkreśleniem postawy łączącej cechy architektury klasycznej z nurtami architektury funkcjonalistycznej 
było zachowanie przez Przybylskiego daleko idącej symetrii w kompozycji planu i bryły, co zdecydowanie odróżniało pawilon Technologii Chemicznej od asymetrycznej kompozycji pawilonu Elektrotechniki, przy zachowaniu plastycznej spójności obu gmachów.

W architektonicznej formie projektowanych dla Politechniki pawilonów, Przybylski nawiązał do geometrycznych nurtów awangardowych, panujących w tym czasie w architekturze europejskiej. Nowa estetyka postulowała kształtowanie form architektonicznych poprzez wydobywanie elementów strukturalnych, odartych z dekoracji i traktowania ich w sposób rzeźbiarski, przy jednoczesnym zachowaniu jedności funkcji i formy.

Wieloczłonowe bryły pawilonów politechnicznych Przybylskiego, o nieregularnych planach i wielopłaszczyznowych elewacjach wpisały się w ceglany, bryłowo-fakturowy, warszawski_funkcjonalizm czasów międzywojnia.

Na całość gmachu Technologii Chemicznej składały się trzy segmenty: dwa bloki, o zróżnicowanej wysokości od jednej do trzech kondygnacji, posiadające wewnętrzne dziedzińce oraz spajający je element centralny, górujący nad całością, rozplanowany całkowicie osiowo i symetrycznie. Masy geometrycznych, przenikających się brył zostały kaskadowo spiętrzone, a punktem kulminacyjnym kompozycji było audytorium na 220 słuchaczy, umieszczone na najwyższym piętrze. Wrażenie wyniesienia części centralnej potęgowała jeszcze różnica poziomów, o półtorej kondygnacji w stosunku do skrzydeł bocznych.

Funkcjonalnie architekt spełnił postulat rozdzielenia struktury wewnętrznej na niezależne jednostki Zakładów: Metalurgii i Metaloznawstwa, Technologii Materiałów Wybuchowych, Technologii Chemicznej Nieorganicznej, Technologii Wielkiego Przemysłu Organicznego i Farbiarstwa, Technologii Fermentacji i Produktów Spożywczych, tak aby każdy z nich posiadał halę technologiczną wysokości dwóch dolnych kondygnacji, z pracowniami technologicznymi i ciężkim sprzętem na parterze, pracowniami chemicznymi, wyposażonymi $\mathrm{w}$ dobrze wentylowane dygestoria na pierwszym piętrze i pracowniami pomiarów fizycznych, fizyko-chemicznych i biochemicznych na piętrze drugim. Część centralna miała przeznaczenie ogólne, wspólne dla wszystkich Zakładów: hole, szatnie, klatki schodowe, pokój rekreacyjny z bufetem i wyjściem na taras, oraz audytoria i pokoje przygotowawcze.

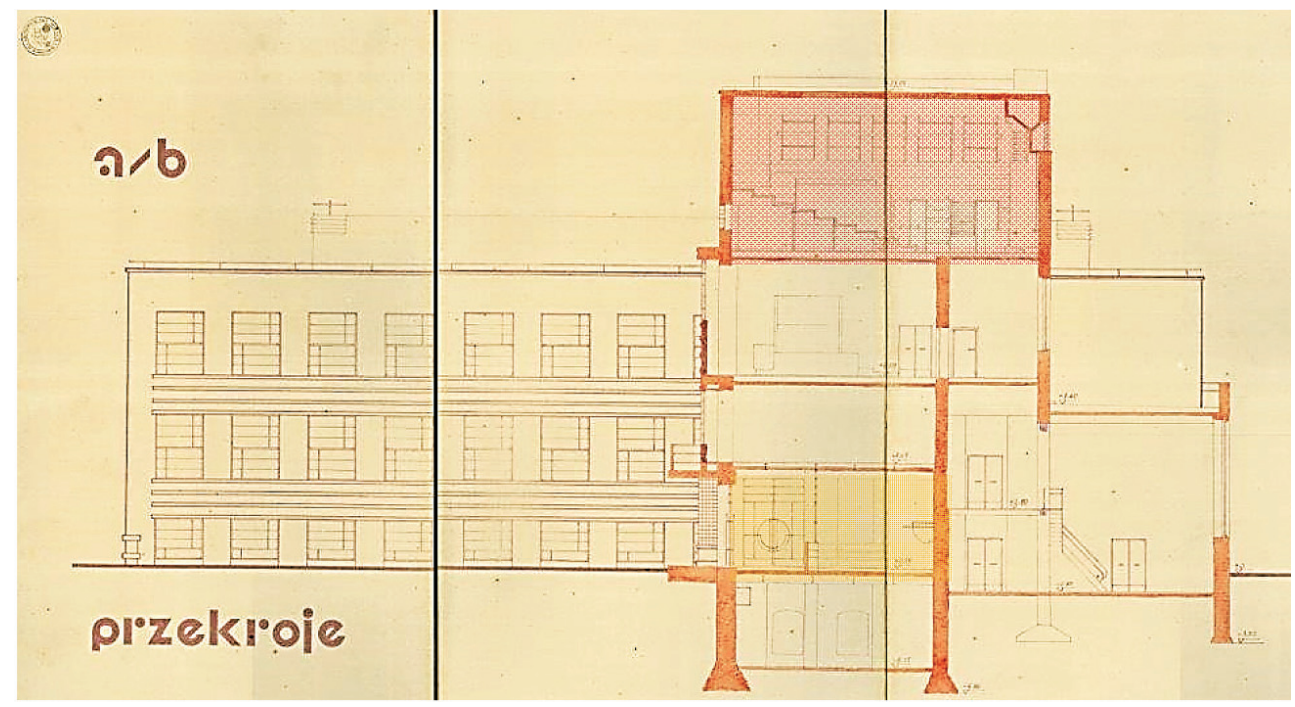

Rys. 4. Przekrój podłużny, wg [1]. Na brązowo zaznaczono audytorium, na żółto hol wejściowy 


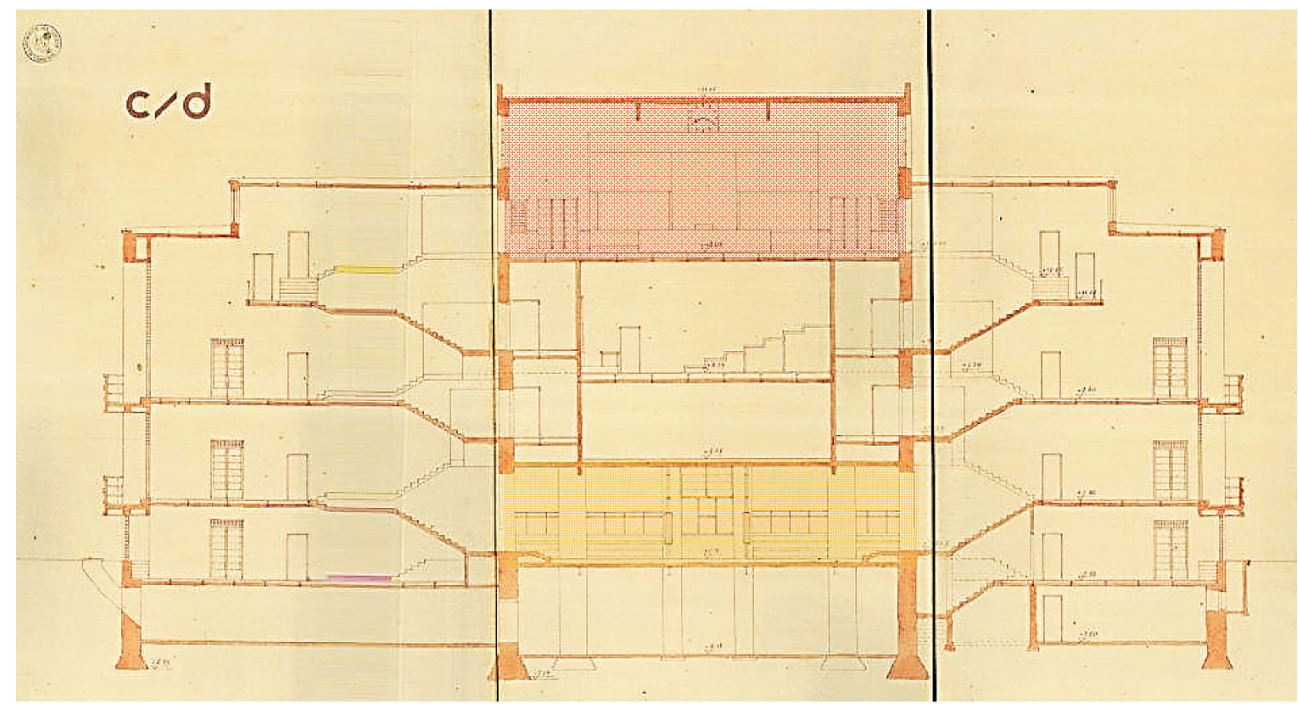

Rys. 5. Przekrój poprzeczny, wg [1]

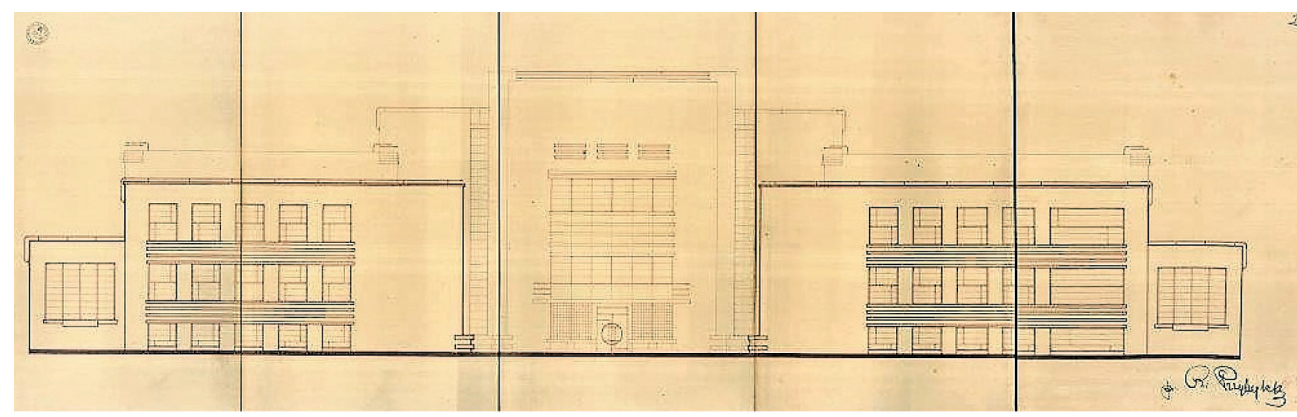

Rys. 6. Projekt elewacji wejściowej, wg [1]

Płaszczyzny elewacyjne rozwiązane zostały w ten sam sposób jak w gmachu Elektrotechniki, co stwarzało wrażenie koherentności obu obiektów. Zakończenie budowy i uroczyste otwarcie obu gmachów w obecności prezydenta Ignacego Mościckiego nastąpiło w 1934 roku.

W czasie wojny budynek uległ poważnemu zniszczeniu. Odbudowano go w latach 1946-48. Obiekt wraz z zespołem Politechniki Warszawskiej między ulicami: Nowowiejską, Al. Niepodległości, Koszykową, Noakowskiego i Pl. Politechniki został wpisany do rejestru zabytków Miasta Stołecznego Warszawy 1 grudnia 1977 roku, nr rejestru 921.

\section{Prace rewaloryzacyjne}

Od kilku lat $\mathrm{w}$ gmachu Technologii Chemicznej trwają prace remontowo-modernizacyjne, mające na celu przywrócenie świetności elewacjom i adaptację wnętrz na nowoczesne laboratoria o światowym standardzie, wyposażone we wszelką niezbędną infrastrukturę. W pierwszym rzędzie przeprowadzono sanację elewacji. W 2008 roku wymieniono okna, 
przywracając przedwojenne podziały i dokonano niezbędnych reperacji ceglanej okładziny. Następnie poddano modernizacji pomieszczenia wydziałowych zakładów. Prace zakończono na rewaloryzacji wnętrz o charakterze ogólnym i w znacznej mierze reprezentacyjnym - holu wejściowego (2014) i dużego audytorium (2016).

\subsection{Rewaloryzacja holu wejściowego}

Rewaloryzacja holu miała przede wszystkim charakter sanacyjny, porządkujący przestrzeń głównego wejścia. W oparciu o rysunki projektowe Czesława Przybylskiego zaprojektowano nowe, przeszklone drzwi z kolistymi antabami i przeszklony wiatrołap wpisany w przestrzeń holu. Zniszczoną terakotową posadzkę odtworzono ze specjalnie dla tej realizacji wyprodukowanych płytek w fabryce Tubądzin. Szatnie domknęły lekkie rolowane kraty liniowe.

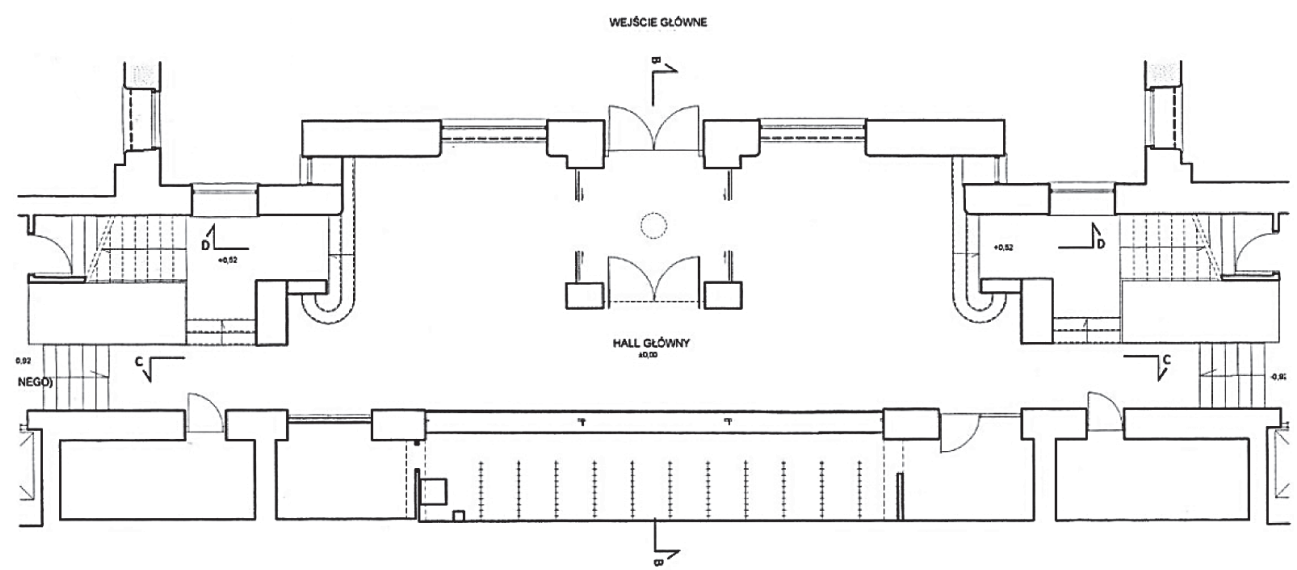

Rys. 7. Rzut holu wejściowego. Projekt arch. Edward Wysocki, 2013 r.

a)

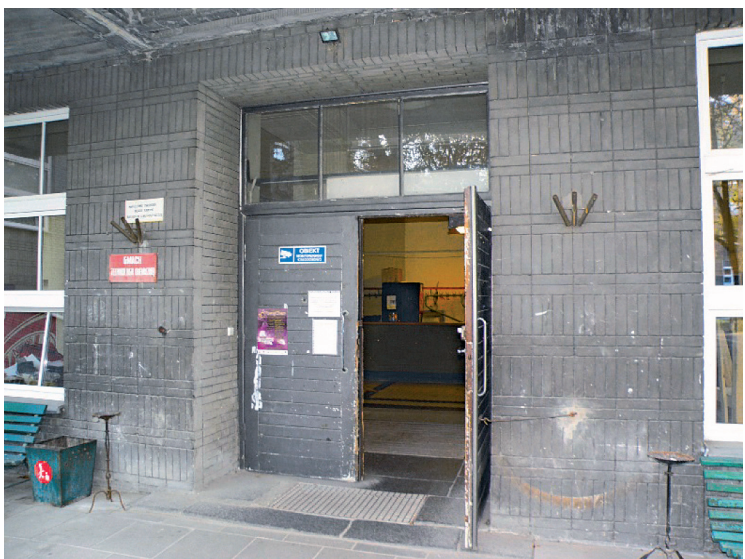

b)

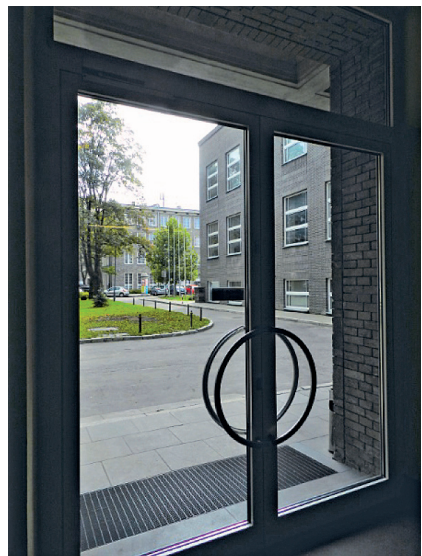

Rys. 8. Drzwi wejściowe, a) stan z przed remontu w 2012 r., b) stan po remoncie, 2017 rok 
a)

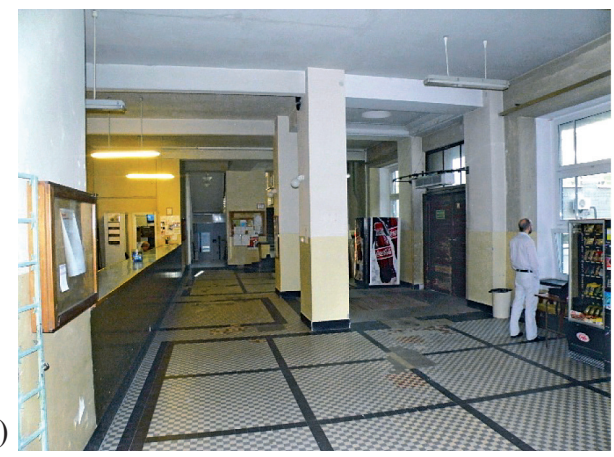

b)

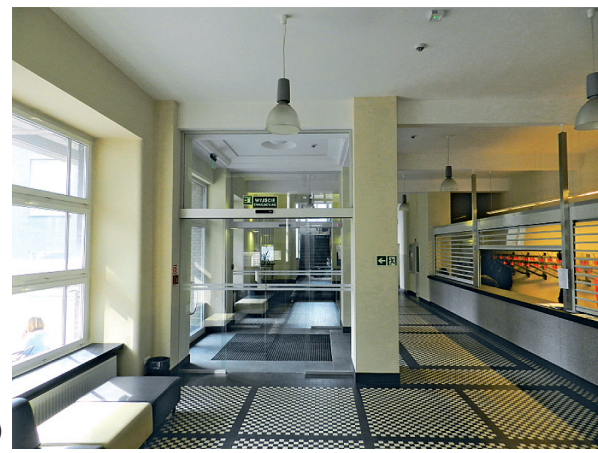

Rys. 9. Hol wejściowy, a) stan z przed remontu w 2012 r., b) stan po remoncie, 2017 rok

\subsection{Rewaloryzacja dużego audytorium}

Pierwotny wystrój dużego audytorium nie jest znany. Można jedynie domniemywać ogólnego charakteru wnętrza na podstawie zachowanego projektu: rzutu najwyższej kondygnacji i przekrojów podłużnego i poprzecznego. Jest na nich czytelna pierwotna struktura przestrzenna wysoko wyniesionego audytorium, z ostatnimi, najwyższymi rzędami załamanymi pod kątem prostym i dostępnymi także poprzez boczne wąskie schody umieszczone po obu stronach korytarza-łącznika, poprowadzonego pod widownią, łączącego część wschodnią i zachodnią gmachu. Także rysunek katedry wyniesionej o dwa stopnie i flankowanej po obu stronach ażurową strukturą (zapewne) dygestoriów, charakteryzuje się typową dla tamtego czasu geometrią form płynnie przechodzących jedna w drugą. Natomiast koncepcja artykulacji ścian wygląda tak jakby nawiązywała do rozwiązania projektowanych elewacji pasmowych podziałów uformowanych w cegle. Materiałem użytym do wystroju wnętrz było zapewne drewno ze względów akustycznych.

W czasie wojny gmach Technologii Chemicznej PW został całkowicie wypalony, a powojenna odbudowa pod koniec lat 40. nie odtworzyła pierwotnej konstrukcji widowni i katedry w dużej auli wykładowej. Świadczy o tym szkic z lat 70., pokazujący schemat stanu istniejącego o płaskiej podłodze.

W 1977 r. audytorium zostało przebudowane na trzy mniejsze, mieszczące 60 i dwa razy po 40 miejsc dla słuchaczy. Sale te ze względu na niską jakość materiałów i tandetne wykonanie szybko się zestarzały i straciły swe walory użytkowe.
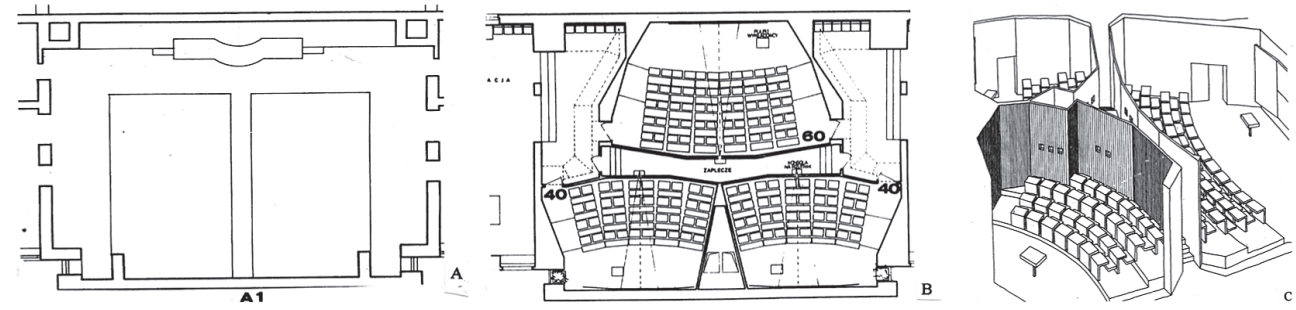

Rys. 10. Projekt modernizacji dużego audytorium na trzy mniejsze, realizacja: arch. A. Krzewiński, 1977. A - stan po powojennej odbudowie, B - projekt przebudowy z lat 70, C - aksonometria projektu z lat 70 . Wg [3] 
Rewaloryzacja audytorium polegała na odtworzeniu pierwotnej struktury przestrzennej wnętrza i nadania mu wystroju utrzymanego w klimacie z lat 30. XX wieku. Największą trudnością było połączenie historycznej formy ze współczesnymi normami dotyczącymi bezpieczeństwa ogniowego, ewakuacji, wyposażenia w niezbędną infrastrukturę techniczną, a także spełnienia wymogów akustycznych. Ze wszystkimi tymi wymaganiami autor projektu arch. Edward Wysocki poradził sobie znakomicie. Ostateczny charakter wnętrza jest współczesny, bez znamion stylizacji, przy jednoczesnym odtworzeniu cech charakterystycznych projektu prof. Przybylskiego.
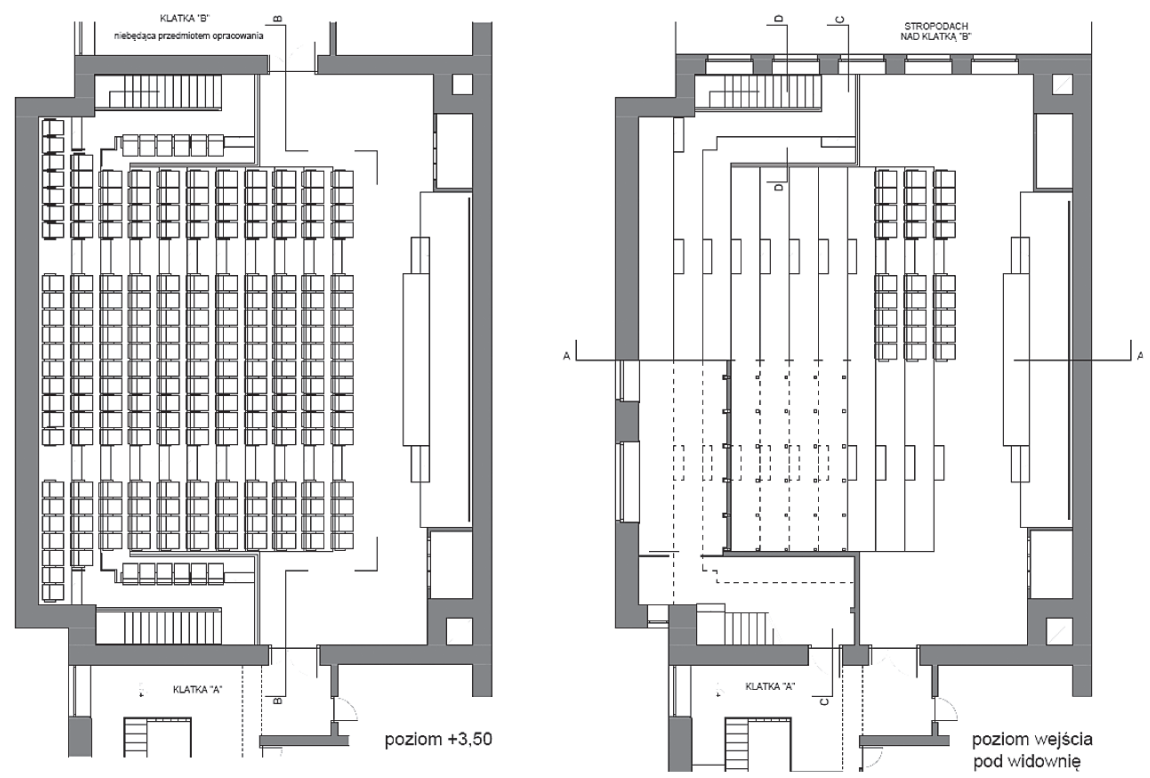

Rys. 11. Projekt modernizacji dużego audytorium, rzuty, arch. E. Wysocki, 2014

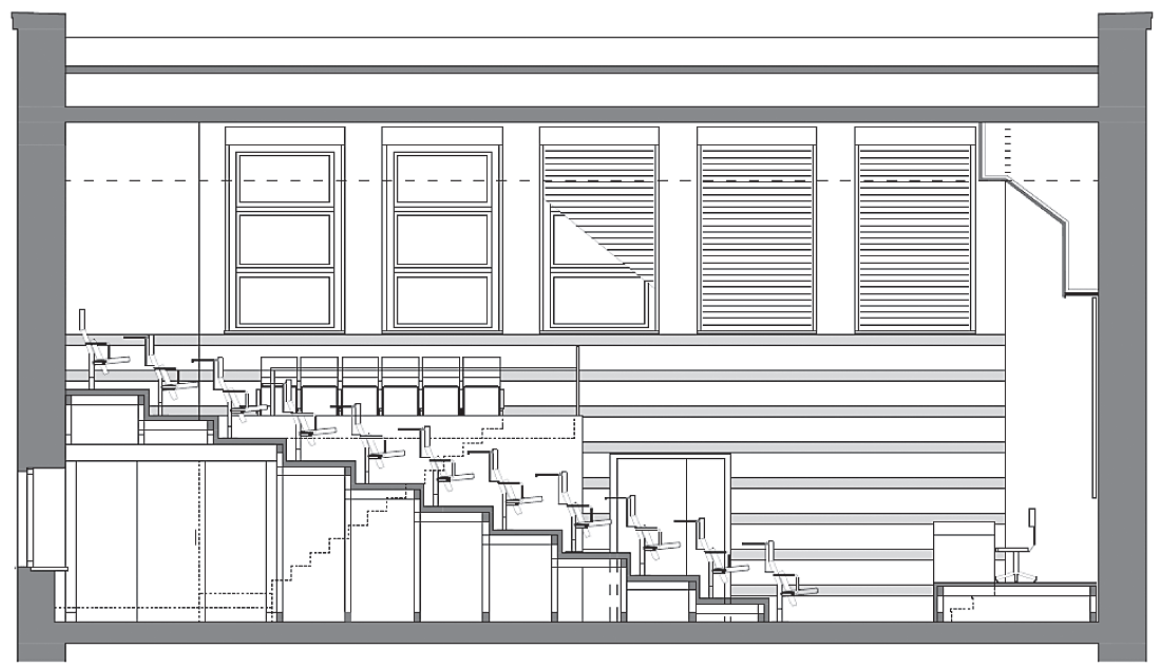

Rys. 12. Projekt modernizacji dużego audytorium, przekrój, arch. E. Wysocki, 2014 


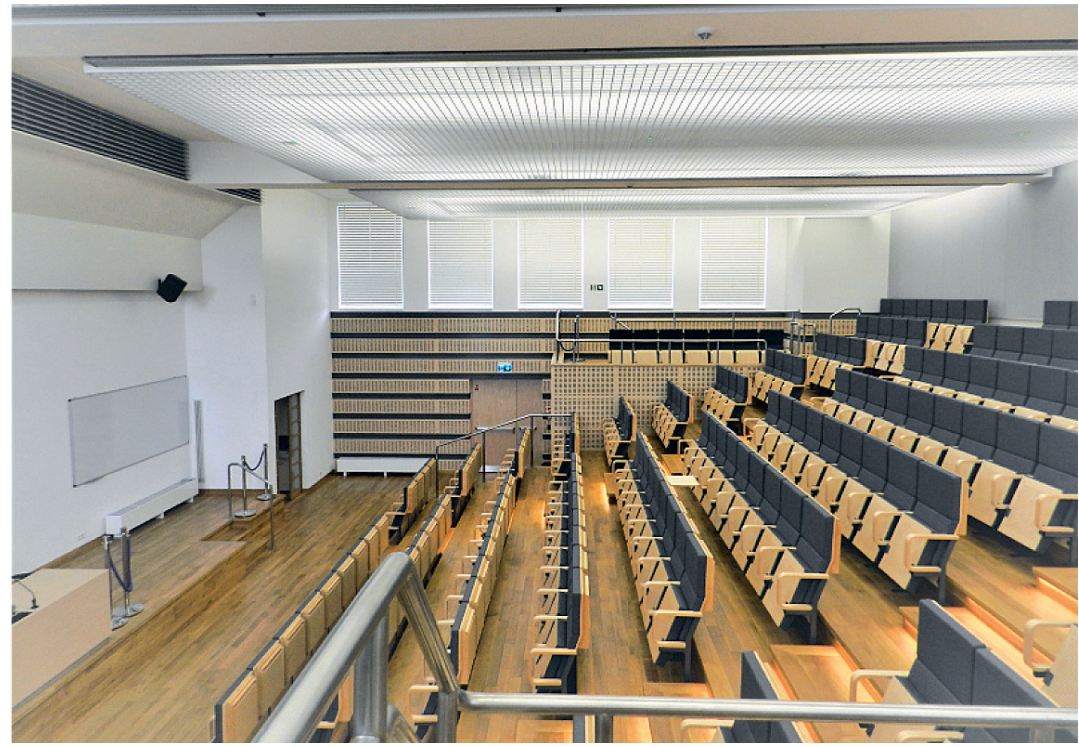

Rys. 13. Duże audytorium po rewaloryzacji z 2016 roku

\section{Podsumowanie}

Przeprowadzone prace rewaloryzacyjne w gmachu Technologii Chemicznej wykonano w oparciu o ścisłą współpracę projektanta z historykiem architektury. Dzięki zachowanemu oryginalnemu projektowi prof. Czesława Przybylskiego możliwa była przestrzenna rekonstrukcja sali wykładowej i przywrócenie pierwotnego układu i charakteru wnętrzom holu wejściowego. Wytyczne sformułowane w wyniku badań historyczno-konserwatorskich stanowiły punkt wyjścia dla podejmowanych decyzji projektowych, które akceptował Stołeczny Konserwator Zabytków. Dobra współpraca pomiędzy administratorami gmachu - Wydziałem Chemii PW, architektem, historykiem architektury i Biurem Stołecznego Konserwatora Zabytków zaowocowała dobrym efektem końcowym. Poprzez odtworzenie przedwojennych form przestrzennych i układów wnętrz przy użyciu współczesnych rozwiązań technologicznych i materiałowych, gmachowi Technologii Chemicznej, zabytkowemu przedstawicielowi przedwojennego warszawskiego modernizmu, przywrócono wartości architektoniczne przy jednoczesnym podniesieniu jego walorów funkcjonalnych.

\section{Literatura}

[1] Archiwum Akt Nowych, Akta MSW, T.II, Cz. I, Sygn. 3490, Pawilon Chemii Pw.

[2] Iwanowski W., Wojcieszak P. Nowy Gmach Technologii Chemicznej budowany przez Tow. „, Studium Technologiczne” dla PW. Przemysł Chemiczny 10-12 (1934) 267-282.

[3] Kucza-Kuczyński K. Zasady modernizacji architektonicznej szkót wyższych. Wydawnictwo PW, Warszawa 1984, s. 28-9.

[4] Wagner A.A. Architektura Politechniki Warszawskiej. Oficyna Wydawnicza Politechniki Warszawskiej, Warszawa 2001.

[5] Wagner A.A. Opinia konserwatorska dotyczaca renowacji holu w gmachu Technologii Chemicznej. Warszawa 2013. 
[6] Wagner A.A. Studium historyczno-konserwatorskie. Audytorium Duże w gmachu Technologii Chemicznej projektu prof. Czestawa Przybylskiego. Warszawa 2014.

[7] Wagner A.A. Czas i miejsce. Architektura Politechniki Warszawskiej. Oficyna Wydawnicza Politechniki Warszawskiej, Warszawa 2015.

[8] Wysocki E. Materiaty pomocnicze dla Stołecznego Konserwatora Zabytków do wydania zaleceń konserwatorskich dotyczacych przywrócenia audytorium w gmachu Technologii Chemicznej Wydziału Chemicznego Politechniki Warszawskiej. Warszawa 2014.

\title{
The restoration of the Chemical Technology Building - the historic building of the Warsaw University of Technology complex
}

\author{
Anna Agata Wagner
}

Faculty of Architecture, Warsaw University of Technology,e-mail: agata.wagner@pw.edu.pl

\begin{abstract}
The Chemical Technology Building was erected in the 1930s. It is one of two buildings designed for the Warsaw University of Technology by prof. Czesław Przybylski, the then Dean of the Faculty of Architecture. The building was designed taking into account specific functional and technological solutions based on the most recent European and American patterns. In the architectural form of the pavilion Przybylski referred to the geometric avant-garde trends. The interlocking cascaded blocks were emphasising their structural elements, treated in a sculptural manner, with care taken to maintain unity of function and form. The whole design was referring to the mass-textural Warsaw functionalism of the grey brick current.

The building was seriously damaged during the Warsaw Uprising (destruction of the ceilings, burning out of the interior). Post-war reconstruction was more akin to modernisation than reconstruction, as the emphasis was put on improving and intensifying its utilitarian functions, omitting the reproduction of the original systems and historical decor.

The last few decades have resulted in a lot of modernization works to the University's buildings. The building of Chemical Technology is a good example of this activities, where renovation and modernization works have been carried out for several years, aimed at restoring the splendor of the facades and adapting the interior to modern laboratories. An important part of these activities is the revalorization of the entrance hall and the main lecture hall. The performed work was based on historical and restoration studies. Thanks to the preserved original project of prof. Czesław Przybylski the spatial reconstruction of Auditorium and restoration of the original interior layout of the entrance hall were possible to accomplish. The use of modern material and technological solutions gave the interiors a contemporary character, without styling, while recreating the characteristics of the design of prof. Przybylski. Good cooperation between building administrators, the architect, the historian of architecture and the preservation and conservation authorities resulted in a good end effect - restoration of architectural values while increasing the utilitarian functions of the historical building of Chemical Technology, an outstanding representative of pre-war Warsaw modernism.
\end{abstract}

Keywords: historic building of the Warsaw University of Technology; pre-war Warsaw modernism; Czesław Przybylski; restoration; modernisation; adaptation. 